\title{
Genetic variation in mutants of chilli (Capsicum annum) Revealed by RAPD marker
}

\author{
L. Mullainathan*, A. Sridevi, S. Umavathi, E. Sanjai Gandhi \\ Division of Cytogenetic and Plant Breeding, Department of Botany, Annamalai University, \\ Annamalai Nagar 608002, India \\ *E-mail address: Imullai@yahoo.co.in
}

\begin{abstract}
The present study was under taken in order to analyze the chemical mutagenesis on Chilli germplasm. In this regard, $\mathrm{K}_{1}$ variety of chilli was subjected to different mutagenic concentration for inducing mutagenesis. The $\mathrm{M}_{3}$ plants exposed to EMS and DES to produce clear difference from the untreated control, thus indicating that mutagenic treatment produce polymorphic regions in the chilli. For extraction of genomic DNA was adopted an improved protocol of CTAB method with slight modification. A total of ten primers were used to screen the polymorphism among the treated populations line tall, tall with chlorophyll deficient, leaf, flower, GMS and DNA damages in maturity mutants were analyzed with control. Out of ten primers, four primers (PGF02, PGF03, PGF04 AND OP107) were successfully amplified in all the samples used for this study. The successful primers were amplified in to 93 products showing an average of 9.3 bands.
\end{abstract}

Keywords: Induced mutation; Chilli; EMS; RAPD analysis

\section{INTRODUCTION}

Chilli is a spice cum vegetable crop of commercial importance, characterized by tempting colour and biting pungency .No dish will fulfill without this spice in India. India is blessed with a plethora of chilli varieties which are used as fresh green fruits, fresh red fruits, and dried red fruits or processed in to chilli paste, chilli powder, oleoresin etc.

The Capsicum genus belongs to the family Solanaceae comprises of approximately 20 species growing at tropical and subtropical regions of the New World (Basu and De, 2003). Chilli $(2 n=24)$ is one of the most important vegetable cum spice crop. The origin of chilli is said to be Mexico, with secondary centers in Guatemala and Bulgaria (Salvador, 2002). It was introduced to Europe by Columbus in $15^{\text {th }}$ century and spread to rest of the globe along the spice trading routes to Africa, India, China and Japan. In $17^{\text {th }}$ century, Portuguese introduced it into India and was incorporated into national cuisines instantly (Bosland and Votava, 2000). The world area and production of chilli is around 15 lakh ha and 70 lakh tonnes respectively. India is the world leader in chilli production followed by China and Pakistan. The bulk share of chilli production is held by Asian countries. The world trade in chilli account for $16 \%$ of the total spice trade in the world, occupying second position after black pepper. 
The rapid advance in the molecular biology and DNA technology has provide never before dreamed of possibilities for increasing both the efficiency and the efficacy of mutation techniques in crop breeding and research. Among them RAPD analysis is suitable for genotyping, phylogenetic analysis and molecular selection (Williams et al., 1990 and Yilzbasioglu et al., 2006). The basis of Randomly Amplified Polymorphic DNA markers is the polymerase chain reaction (PCR) amplification with arbitrarily chosen primers the initiate DNA synthesis from sites to which the primers is matched. So RAPD were designed to solve the problem of lack of pre - existing DNA sequence information.

\section{MATERIALS AND METHOD}

The dry and dormant seeds of the chilli variety Kovilpatti ${ }_{1}\left(\mathrm{~K}_{1}\right)$ were obtained from Tamilnadu Agricultural Research Station, Kovilpatti, Tamilnadu. Chemical mutagens such as ethyl methane sulphonate (EMS) and diethyl sulfate (DES) were used for this study at various concentrations to induce mutagenesis. This chemical was also obtained from HI-MEDIA Laboratories, Mumbai. Among the various mutagenic treatments, some of the macro mutants (morphological) were isolated from $\mathrm{M}_{2}$ generation. Seed samples were germinated in plastic pots until seedlings were grown up to two to three leaf stage. Five to six seedlings were taken from each mutant namely, tall, tall with chlorophyll deficient, leaf, flower, GMS mutant and early maturity mutants. In order to analyze the molecular basis, RAPD technique was used to detect the polymorphism in the base pairs of DNA among the mutants.

Genomic DNA was extracted by adopting the CTAB method outlined by Doyle and Doyle (1990) with slight modification.

The young seedling leaf samples (1 gram) were ground into fine powder in liquid nitrogen using sterilized pestle and mortar. Pre-warmed extraction buffer in the amount of $800 \mu \mathrm{L}$ was added to the samples and ground again in buffer. Samples were taken in $1.5 \mathrm{ml}$ eppendorf tube with a small spatula or glass rod after the contents were incubated at $55{ }^{\circ} \mathrm{C}$ for $45 \mathrm{mts}$. After following the incubation periods, samples were cooled at room temperature then centrifuged at $10,000 \mathrm{rpm}$ for $10 \mathrm{mts}$ and supernatant was transferred to a fresh tube. Samples were extracted with equal volume of Chloroform: Iso amyl alcohol (25:1) gently mixed by tilting over 40-50 times. At this stage it was observed that incubating the samples for at least $15 \mathrm{~min}$ on ice $\left(4^{\circ} \mathrm{C}\right)$ increased the efficiency. After centrifugation, the supernatant was transferred to a fresh tube having $7.5 \mathrm{M}$ ammonium acetate and isopropyl alcohol and then the samples were incubated on ice for 15 minutes. The step is not mandatory, but it can be prolonged for several hours. The samples were centrifuged for 10 minutes at 10,000 rpm and $70 \%$ ethanol $(500 \mu \mathrm{l})$ was added to the pellet and centrifuged again for 10 minutes at $10,000 \mathrm{rpm}$. Then the supernatant was discarded and the pellet saved air dried for $10 \mathrm{mts}$ and pellet was dissolved in an appropriate amount of TE Buffer $(30-60 \mu \mathrm{l})$. The samples were treated with ribonuclease (RNase $-10 \mathrm{mg} / \mathrm{ml}$ ) and stored at $-20^{\circ} \mathrm{C}$.

DNA was quantified via spectrophotometric measurement of UV absorption at $260 \mathrm{~nm}$ (Shimadzu UV-260). DNA was also quantified by means of agarose gel electrophoresis with Ethidium bromide fluorescence and a 100-bp DNA ladder (Fermentas) as the DNA size marker. 


\section{RESULT}

Seven Capsicum annuum var. $\mathrm{K}_{1}$ mutants were subjected to RAPD assay to analyze for identifying DNA polymorphism. Ten random decamer primers revealed a high DNA polymorphism among the mutant populations like tall, tall with chlorophyll deficient, leaf, flower, GMS and early maturity mutants were analyzed.

A total of 93 bands scored of which 48 bands were polymorphic with an average of 51.61 per centage polymorphism. Only four primers (PGF02, PGF03, PGF04 and OPI07) showed highest polymorphism and the primer PG10 gave the lowest polymorphism $(25.00 \%)$ (Table 1). The Jaccard's coefficient similarity varied from 0.702 to 0.867 (Table 1).

Table 1. Analysis of RAPD banding pattern for Chilli (Capsicum annuum L.).

\begin{tabular}{|c|c|c|c|c|c|}
\hline S. No & Primer Code & $\begin{array}{c}\text { Total number } \\
\text { of bands }\end{array}$ & $\begin{array}{c}\text { Polymorphic } \\
\text { bands }\end{array}$ & $\begin{array}{c}\text { Monomorphic } \\
\text { bands }\end{array}$ & $\begin{array}{c}\text { Per centage of } \\
\text { polymorphism }\end{array}$ \\
\hline 1 & PGF02 & 13 & 10 & 3 & 76.92 \\
\hline 2 & PGF03 & 12 & 8 & 4 & 66.66 \\
\hline 3 & PGF04 & 14 & 10 & 4 & 71.42 \\
\hline 4 & OPC07 & 11 & 6 & 4 & 54.55 \\
\hline 5 & OPC11 & 7 & 3 & 4 & 42.86 \\
\hline 6 & OPC-12 & 6 & 2 & 6 & 33.33 \\
\hline 7 & PGF01 & 9 & 2 & 6 & 33.33 \\
\hline 8 & PG10 & 8 & 3 & 5 & 37.5 \\
\hline 9 & OPA- 08 & 8 & 1 & 4 & 20.00 \\
\hline 10 & OPA -13 & 5 & 48 & 32 & 428.24 \\
\hline & Total & 93 & 4.8 & 3.2 & 51.61 \\
\hline & Average & 9.3 & & & \\
\hline
\end{tabular}

Based on the dendrogram constructed by Jaccard's coefficient similarity in Chilli var. $\mathrm{K}_{1}$ mutants indicated two clusters; one comparing control and other cluster consist of genic male sterile mutant.

The first cluster subdivided in to three clusters which had tall, flower and early maturity mutants. The early maturity mutant cluster again subdivided into tall with chlorophyll mutant and leaf mutants. The genic male sterile mutant has lowest similarity with more variation from other mutant characters (Fig. 1). 


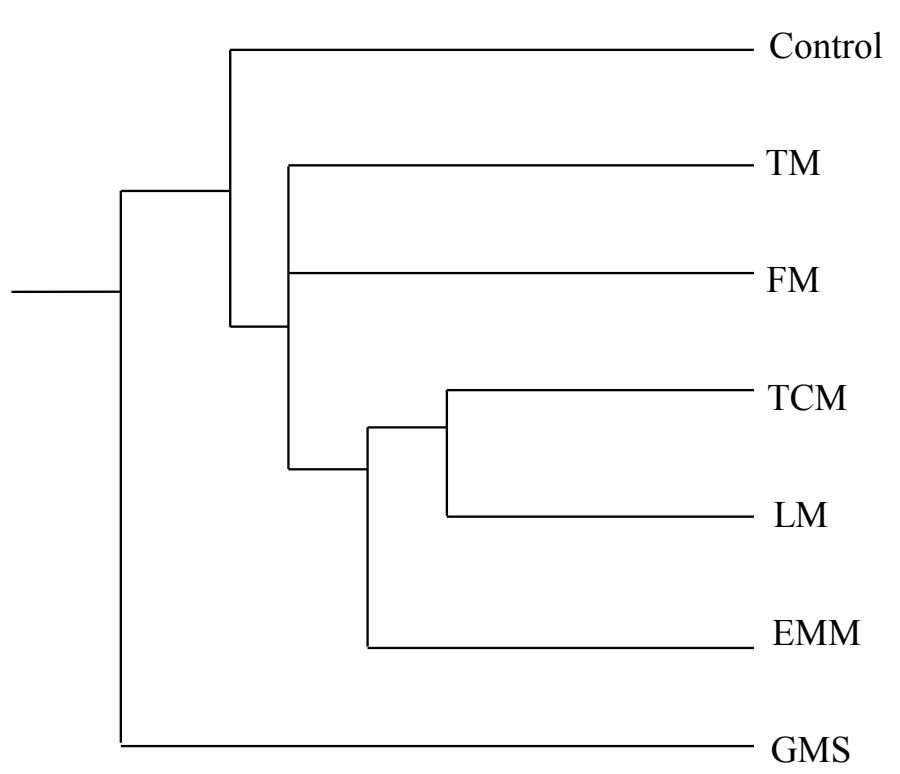

Fig. 1. Dendrogram analysis of Six mutants and control of Chilli var. $K_{1}$. Cophenetic Correlation Coefficient $(\mathrm{CP})=0.87610$.

\section{DISCUSSION}

The RAPD analysis of the $\mathrm{M}_{3}$ generation plants exposed to EMS and DES produce clear difference from the untreated control, thus indicating that mutagenic treatments produce polymorphic regions in the chilli mutant (Plate - I and II). This may be due to the reason that the variation might be stabilized upon consecutive generations.

The variation in band intensity and disappearance of some bands may correlate with the level of photoproducts in DNA template after radiation, which can reduce the number of binding sites for Taq polymerase.

Appearance of new bands in some cases can be explained as a result of different DNA structural changes (breaks, transpositions, deletions etc.). Thus, the estimate on the existence of mutation and structural alterations in plant DNA after impact of radiation on the bases of DNA patterns could be obtained after RAPD markers with the set of primers. A similar opinion was reported by Wachira et al., (1995). Arulbalachandran et al., 2009 also reported the polymorphism revealed by RAPD due to deletion and/or addition may be caused by variation in DNA binding pattern by gamma rays and EMS.

A total of ten primers were used to screen the polymorphism between the mutants and control. It revealed a high DNA polymorphism among the treated populations like tall, tall with chlorophyll deficient, leaf, flower, GMS and early maturity mutants were analyzed with control. The DNA fragments with different molecular weights were amplified and the product size ranged between 250-6000 bp. Out of ten primers, four primers (PGF02, PGF03, PGF04 and OPI07) have successfully amplified in all the samples used for the study. These four successful primers have amplified 93 products showing an average of 9.3 bands (Table 1). Out of total 48 products amplified, $51.61 \%$ were found to be polymorphic. 


\section{PLATE - I \\ RAPD PROFILE - Capsicumamum var $\mathrm{K}_{1}$}

Fig 1: Gel electrophoresis showing PCR profiles of amplified DNA from control and mutants using primer PGF02

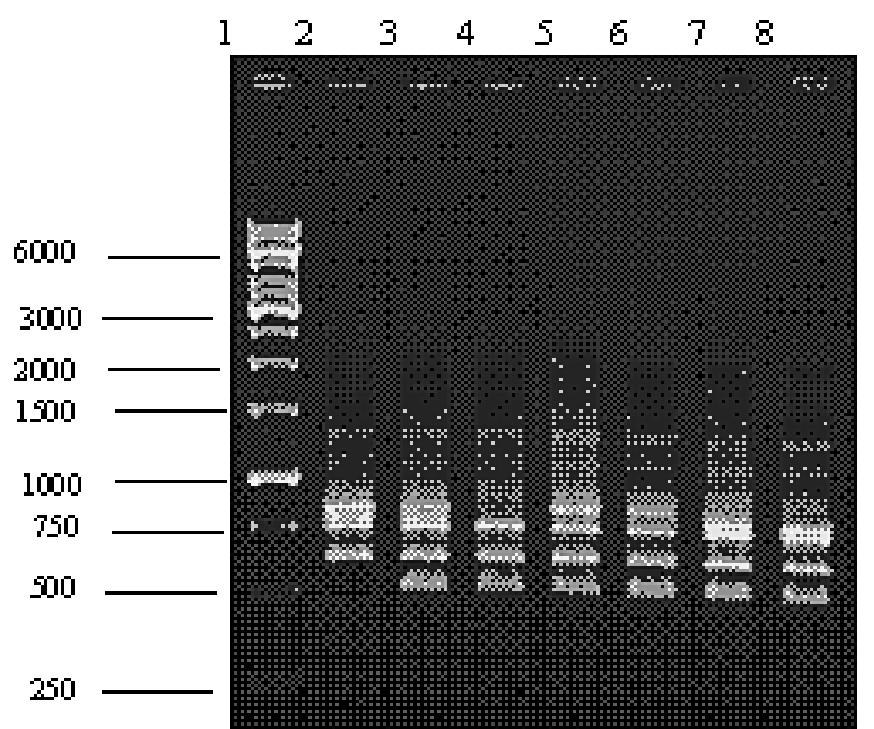

Lane 1- Marker, Lane 2-Control; Lane 3- Tall, L ane 4- Tall wiflh chlorophyll def ir ient; Lane 5-Le af; Lane 6-Fower; Lane 7-GMS mutart and Lane 8-Early maturity mutarts

Fig 2: Gel electrophoresis showing PCR profiles of amplified DNA from control and mutants using primer PGF03

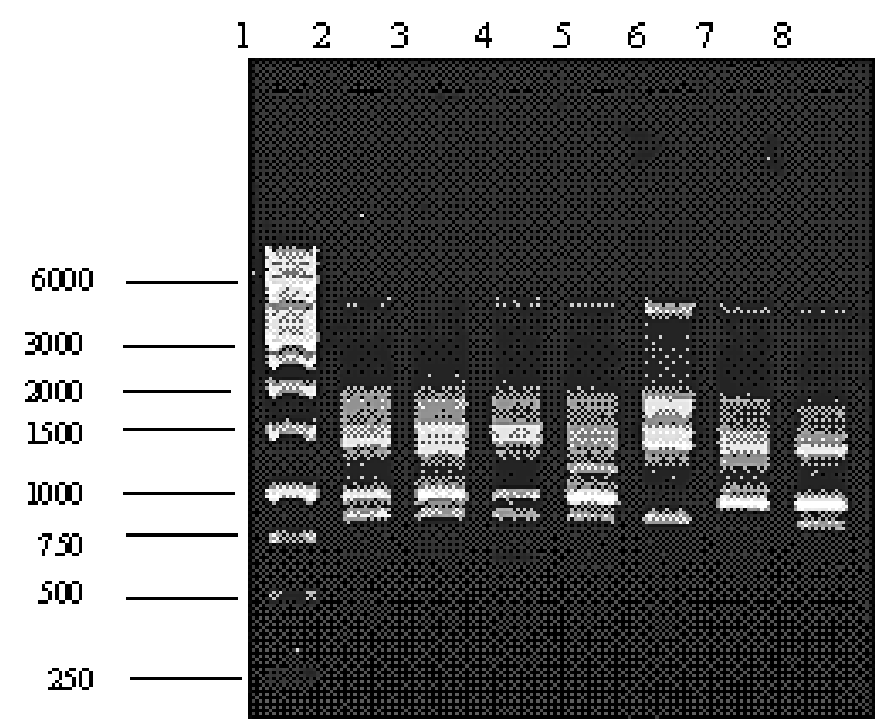

Lane 1- Marker, Lane 2 - Control; Lane 3-Tall, Lame 4-Tall with chlor ophyll deficient; Lane 5-Le af; Lane 6-Flower; Lane 7-GMS mutart; Lane 8-Early mathrity moltants 


\section{PLATE - II \\ R.APD PROFILE - Capsicumannum va $\mathrm{K}_{1}$}

Fíg 3: Gel electrophoresis showing PCR profiles of amplified DNA from control and mutants using primer PGFO2

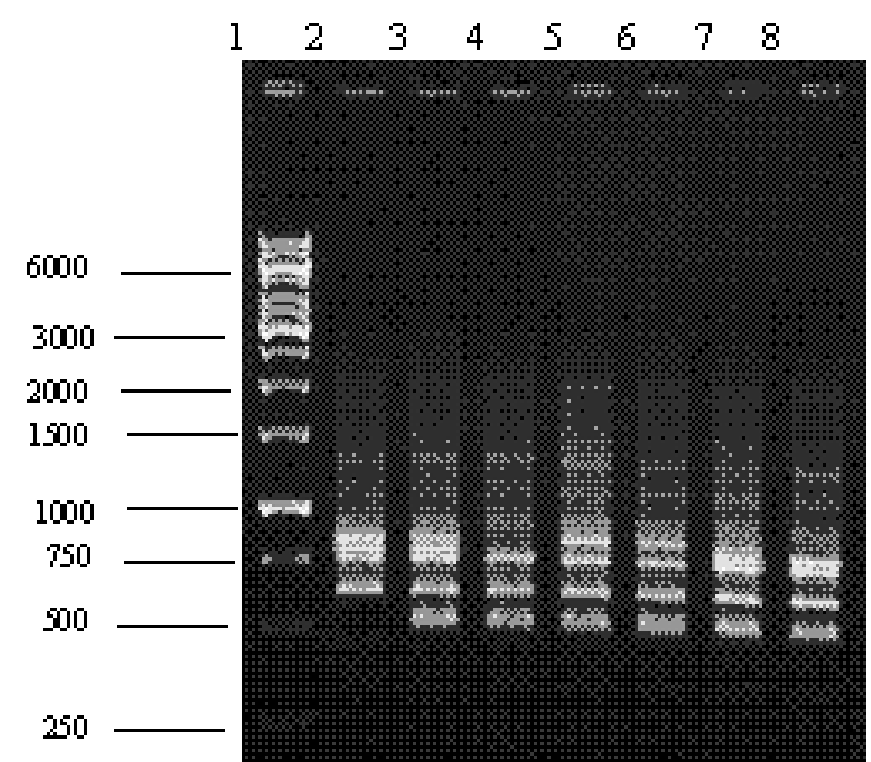

Lame 1- Marker, Lane 2-Cortrol; Lane 3- Tall, L ane 4- Tall wifl chlorophyll def ir iert; Lane S-Leaf; Lane 6-Flower; Lare 7-GM S mutart and Lane 8-Early manility mutarts

Fig 4: Gel electrophoresis showing PCR profiles of amplified DNA from control and mutants using primer PGFOS

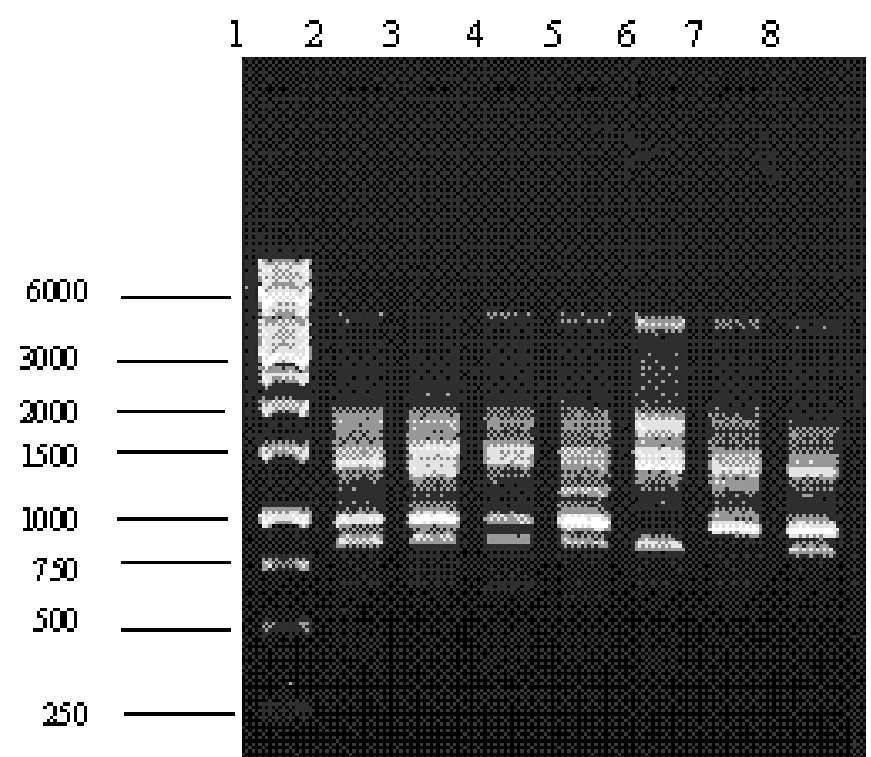

Lane 1- Marker, Lane 2 - Control; Lave 3-Tall, Lane 4-Tall with chlorophyll deficient;

Lane 5-Le af; Lane 6-Flower; Lane 7-GMS montant; Lane 8-Early matirity montants 
The RAPD analysis of the $\mathrm{M}_{3}$ generation plants exposed to mutagen treatments produce clear difference from the mutant and untreated control, thus indicating that mutagenic treatments produce polymorphic regions in the chilli mutant. Similar varied levels of polymorphism have been reported in gamma ray, EMS and combination treated seeds by Ashok Kumar and Ponnuswami (2010) in paprika, (Subramanian et al., 2000) in groundnut and (Senthamizh Selvi et al., 2008) in amla.

\section{CONCLUSION}

Six mutants and control were analyzed with molecular markers that showed a greater DNA polymorphism with variation in genome level. It can also provide a useful tool for mutant characterization, conservation and utilization as well as genetic and breeding studies in Chilli (Capsicum annuum L.). The PCR based molecular markers are widely used at molecular level because they provide markers that are not influenced by changing conditions of environment.

\section{References}

[1] Arulbalachandran D, 2006. Effect of physical and chemical mutagenesis in black gram (Vigna mungo (L.) Hepper). Ph.D. Thesis, Faculty of Science, Annamalai University, Annamalai Nagar, India.

[2] Ashok Kumar G., V. Ponnuswami, Research Journal of Agricultural Sciences 1(3) (2010) 193-195.

[3] Atienzar F. A., P. Venier, A. N. Jha, M. H. Depledge., Mut. Res. Gen. Tox. Environ. 521(1-2) (2002) 151-163.

[4] Basu S. K., A. K. De, 2003. Capsicum: Historical and Botanical Perspectives.

Citation information Capsicum. The genus Capsicum Print ISBN: 978-0-415- 29991-6, eBook ISBN: 978-0-203-38115.

[5] Bosland P. W., F. J. Votava, Peppers, Vegetable and Spice Capsicums. CABI Publishing, 2000, p. 204.

[6] Doyle J. J., J. L. Doyle, Focus 12 (1990) 13-14.

[7] Jaccard P., Bull. Soc. Vaud. Sci. Nat. 44 (1908) 223-270.

[8] Naugžemys D., S. Zilinskaite, J. Denkovskij, J. Patamsyte, J. Literskis, D. Zvingila, Biologia 53(3) (2007) 34-39.

[9] Salvador M. H., Genetic resources of chilli (Capsicum spp.) in Mexico. Proc. of the $16^{\text {th }}$ Int. Pepper Conf., Tampico, Tamaulipas, Mexico, November, 2002, pp. 10-12.

[10] Senthamizh Selvi B., V. Ponnuswami, P. S. Kavitha, Adv. Nat. Appl. Sci. 2(3) (2008) 129-134.

[11] Subramanian V., Gurtu S., Nageswara Rao, Nigam S. N., Genome 43 (2000) 656-660.

[12] Wachira F. N., Waugh R., Hackett C. A., Powell W., Genome 38 (1995) 201-210. 
[13] Williams J. G. K., A. R. Kubelik, K. J. Livak, J. A. Rafalski, S. V. Tingey, Nucleic Acids Res. 18 (1990) 6531-6535.

[14] Yüzbasığlu E., S. Özcan, L. Açık, Genet. Resour. Crop Ev. 53 (2006) 507-514.

[15] E. Sanjai Gandhi, A. Sri Devi, International Letters of Natural Sciences 5 (2014) $18-23$.

( Received 05 February 2014; accepted 16 February 2014 ) 